\title{
Effects of sowing methods and nitrogen rates on photosynthetic characteristics, yield, and quality of winter wheat
}

\author{
H. NOOR (iD), Q. WANG, M.A. ISLAM (D) , M. SUN ${ }^{+}$, W. LIN, A.X. REN, Y. FENG, S.B. YU, \\ N. FIDA, S.F. DONG, P.R. WANG, L. LI, Z.X. WANG, R.R. ZHANG, Q.L. ZHAO, P.C. DING, \\ and Z.Q. GAO
}

College of Agriculture, Shanxi Agricultural University, 030801 Taigu, Shanxi, China

\begin{abstract}
Sustainability of winter wheat yield under dryland conditions depends on improvements in crop photosynthetic characteristics and crop yield. Therefore, studying the effects of different sowing methods and nitrogen rates on photosynthetic characteristics of flag leaves, nitrogen translocation, and yield could be an effective strategy to improve the crop yield. In this study, four nitrogen application concentrations and two sowing methods were used. The results showed that the photosynthetic rates were the highest at different stages of wide-space sowing (WSS) after flowering. Nitrogen concentration of $240 \mathrm{~kg} \mathrm{ha}^{-1}$ improved the photosynthetic characteristics and significantly increased the net photosynthesis, stomatal conductance, and transpiration rate after flowering and significantly reduced the intercellular $\mathrm{CO}_{2}$ concentration compaired to other nitrogen concentrations. Our overall findings suggested that WSS nitrogen treatment with $240 \mathrm{~kg} \mathrm{ha}^{-1}$ enhanced photosynthetic characteristics of flag leaves and nitrogen content of the plants leading to high yield under dryland conditions.
\end{abstract}

Keywords: $\mathrm{CO}_{2}$; drill sowing; nitrogen fertilizer; photosynthetic characteristics; wide-space sowing.

\section{Introduction}

The yield of winter wheat (Triticum aestivum $\mathrm{L}$.) in dryland areas is unstable and substantially lower than the average yield in other areas of China and other European countries. Stabilizing the yield of dryland wheat and improving the overall production and grain quality of dryland areas have always been the main task of research for cultivation work in the arid regions of North China (Li et al. 2002, Ma et al. 2005). The Loess Plateau in China covers about 0.65 million $\mathrm{km}^{2}$ area and has the population of 108 millions (Wang et al. 2016). The Loess Plateau has a semiarid climate with low and variable rainfall from 300-700 mm (Li et al. 2010). Nitrogen (N) deposition has dramatically altered terrestrial ecosystem properties and processes, such as plant nutrient cycling, photosynthetic carbon

\section{Highlights}

- Nitrogen fertilizer can significantly improve the net photosynthetic rate of winter wheat

- Different sowing methods can promote an increase of intercellular $\mathrm{CO}_{2}$

- WSS with nitrogen concentration of $240 \mathrm{~kg} \mathrm{ha}^{-1}$ improves wheat yield in Loess Plateau area
Received 12 November 2020

Accepted 12 March 2021

Published online 29 April 2021

${ }^{+}$Corresponding author

e-mail:sm_sunmin@126.com

Abbreviations: $\mathrm{AS}$ - anthesis stages; $C_{\mathrm{i}}-$ substomatal $\mathrm{CO}_{2}$ concentration; DS - drill sowing; $E$ - transpiration rate; EFS - early grainfilling stage; $g_{\mathrm{s}}$ - stomatal conductance; LFS - late grain-filling stage; MFS - middle grain-filling stage, PA-M - precipitation anthesis to maturity; PF - precipitation fallow, $\mathrm{PGT}$ - precipitation growth total; $\mathrm{PJ}-\mathrm{A}$ - precipitation jointing to anthesis; $P_{\mathrm{N}}-$ net photosynthetic rate; PS-J - precipitation sowing jointing; PT - precipitation total; WSS - wide-space sowing.

Acknowledgements: The authors are thankful to 'Modern Agriculture Industry Technology System Construction' (No. CARS-3124), The National Key Research and Development Program of China (No. 2018YFD020040105), The Sanjin Scholar Support Special Funds Projects, National Natural Science Foundation of China (No. 31771727), The '1331' Engineering Key Innovation Cultivation TeamOrganic Dry Cultivation and Cultivation Physiology Innovation Team (No. SXYBKY201733) for financial support of this study. Conflict of interest: The authors declare that they have no conflict of interest. 
assimilation, and species diversity (Liu et al. 2015, Mao et al. 2018). Under water stress, the grain-filling process is sustained mainly by photosynthesis in the upper parts of wheat plants, such as the flag leaves and wheat ears (Carr and Wardlaw 1965, Tambussi et al. 2005). Previously, researchers thought that photosynthesis of the flag leaves was supplying the majority of assimilates for grain filling (Evans et al. 1975). However, several studies showed that wheat ear is an important source of photosynthetic carbon assimilation during grain filling, especially if plants are under nitrogen fertilizer (Bort et al. 1994, Jia et al. 2015). Now it is accepted that nitrogen of ear photosynthesis is a major contributor to the final grain yield. It was proposed that high photosynthesis in wheat leaves is an important trait for nitrogen assimilation in wheat (Tambussi et al. 2007).

The relative stability of ear photosynthetic apparatus and relatively high photochemical efficiency might help in maintaining ear photosynthesis during the grain filling period in water-deficient plants (Martinez et al. 2003). There are several traits that likely support the superior photosynthetic performance of wheat ears compared to the flag leaves in wheat under drought conditions. The wheat ear is closer to the grain, which is the main photosynthetic sink (O'Brien et al. 1985, Tambussi et al. 2005). The stomata are micro valves which are responsible for gas exchange, specifically acquiring $\mathrm{CO}_{2}$ from the air and transpiring moisture from a plant (Abbad et al. 2004). A xeromorphic anatomy has been detected in wheat ear glume increasing accumulation of $\mathrm{CO}_{2}$ for photosynthesis (Teare et al. 1972). Photosynthesis in crops is changed by the addition of nitrogen and sowing is influenced, too. WSS is a modified form of drill sowing in which seeds are distributed evenly and in the same plane (Tao et al. 2018). In N-limited ecosystem, $\mathrm{N}$ deposition can satisfy plant $\mathrm{N}$ demand and stimulate photosynthetic capacity and plant growth (Peñuelas et al. 2013, Mao et al. 2018). The species-specific response to increased $\mathrm{N}$ deposition depends largely on their physiological adaptations in natural grassland community (Chen et al. 2005, Bubier et al. 2011). Different functional groups exhibit divergent photosynthetic capacity and nutrient cycling in response to altered $\mathrm{N}$ availability (Hikosaka 2004). The uniform sowing significantly increased the nitrogen rate and grain yield without a significant decline in grain protein (Bubier et al. 2011).

Fertilizers constitute an integral part of improved crop production technology. Nitrogen $(\mathrm{N})$ is an essential mineral nutrient for plant growth, expands soil fertility and crop productivity (López-Bellido et al. 2012, Wang et al. 2012). A proper amount of $\mathrm{N}$ fertilizer application is considered a key for high crop production (Liang et al. 2019). An increase in grain yield is often associated with a low protein content (Triboi and Triboi-Blondel 2002). In China, farmers are excessively applying $\mathrm{N}$ fertilizers to sustain further increase grain yield, but grain yield does not keep a synchronous increase with the excessive $\mathrm{N}$ application (Meng et al. 2016). For dryland wheat production, the major task is to use a method which could effectively enhance the soil moisture consumption. Wide- sowing method has been used for dryland wheat production and results have shown that compared to drill sowing, the WSS can increase the growth of wheat at various growth stages and improve the efficiency of water uptake and increase the yield (Sun et al. 2015).

The objective of this study was to find the best sowing method and optimize doses of nitrogen to increase the yield of winter wheat crop. Thus, we used two sowing methods, i.e., wide-space sowing (WSS) and drill sowing (DS) and four nitrogen application concentrations set as $180,210,240$, and $270 \mathrm{~kg}(\mathrm{~N}) \mathrm{ha}^{-1}$ (N180, N210, N240, N270, respectively) to analyze the photosynthetic characteristics and yield-related traits in winter wheat. Our findings showed that WSS with N240 enhances the photosynthetic characteristics of flag leaves and promotes high yield. Therefore, the WSS with N240 would be a valuable management practice to improve wheat yield in Loess Plateau area of China.

\section{Materials and methods}

Experimental site: The experiment was conducted outdoors at the Wenxi experimental site of Shanxi Agriculture University located in the southeastern part of the Loess Plateau, China $\left(110.15^{\circ} \mathrm{E}\right.$ and $\left.34.35^{\circ} \mathrm{N}\right)$. It is a typical semiarid area with an altitude of 450-700 m. The average annual temperature is $11-13^{\circ} \mathrm{C}$. The average annual rainfall is $450-630 \mathrm{~mm}$, of which $60-70 \%$ precipitation is concentrated in July-September (Fig. 1). Winter wheat and maize are the main crops and they were harvested in early October of the same year.

Experimental design and treatments: The experiment, a typical winter wheat-summer fallow, started with the winter wheat, and ended when the winter wheat was harvested in June 2017, covering two successive wheat crops at the same experimental plot. The two factors split-plot design was adopted and two sowing methods were used, i.e., wide-space sowing (WSS) and drill sowing (DS). An entire terraced field was divided into two parts. A different field

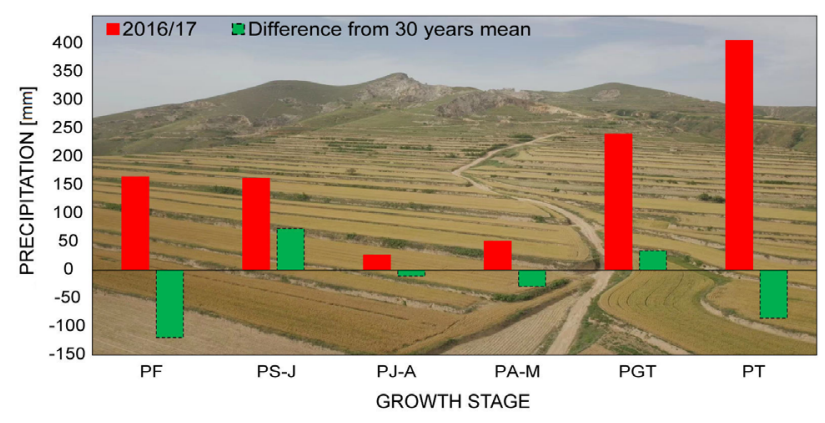

Fig. 1. Precipitation during study year (2016-2017) and difference in precipitation from average precipitation in last 36 years (1981-2017) in different growth stages of wheat at the experimental site in Wenxi, China. PF, PS-J, PJ-A, PA-M, PGT, and PT indicate the fallow precipitation and precipitation from sowing to jointing, jointing to anthesis, anthesis to maturity, precipitation growth total, and total precipitation, respectively. 
was used each year. Seeds of the winter wheat (Triticum aestivum L.), cultivar 'Yunhan 20410', were obtained from the Shanxi Agriculture Bureau, Wenxi, China. Nitrogen was applied in four application concentrations set as 180 , 210, 240, and $270 \mathrm{~kg}(\mathrm{~N}) \mathrm{ha}^{-1}$ (N180, N210, N240, N270, respectively). All treatments were replicated three times. The area of each plot was $30 \mathrm{~m}^{2}(5 \times 6 \mathrm{~m})$. Winter wheat was sown in October in 2015 and 2017 and harvested in June of the following year. Stubble (about $25 \mathrm{~cm}$ high) was left in field after harvesting wheat. After the previous corn harvest, the straw was returned to the field. Before sowing, the basal application of phosphate fertilizer and potash fertilizer, $150 \mathrm{~kg}\left(\mathrm{P}_{2} \mathrm{O}_{5}\right) \mathrm{ha}^{-1}$ and $90 \mathrm{~kg}\left(\mathrm{~K}_{2} \mathrm{O}\right) \mathrm{ha}^{-1}$, was applied to the soil. The nitrogen fertilizer was applied to the base ratio of $6: 4$, during the whole growing season, weed was well controlled by hand and no irrigation was applied in each experimental year. The planting density was $315 \times 10^{4}$ plants ha ${ }^{-1}$.

Photosynthetic characteristics: The net photosynthetic rate $\left(P_{\mathrm{N}}\right)$, transpiration rate $(E)$, intercellular $\mathrm{CO}_{2}$ concentration $\left(C_{\mathrm{i}}\right)$, and stomatal conductance $\left(g_{\mathrm{s}}\right)$ of the flag leaf were measured by $L I-340$ hand-held photosynthesis measurement system (LI-COR, Inc., Lincoln, Nebraska, USA) from 9:00 to 11:00 h. In order to compare photosynthetic characteristics of leaves with a similar developmental age, gas-exchange measurements of each cultivar were conducted immediately after the flag leaves fully expanded. The environmental conditions in the leaf chamber were tightly controlled by the gas-exchange instrument. Each measurement was repeated three times under the same conditions [irradiance of $200 \mu \mathrm{mol}$ (photon) $\mathrm{m}^{-2} \mathrm{~s}^{-1}$; temperature of $26.7^{\circ} \mathrm{C}$; relative humidity of $70.3 \%$ ], which minimized the variations of gas-exchange parameters caused by different ambient environmental conditions. To minimize the diurnal variation of photosynthesis, the measurements were suspended when significant midday depression occurred.

For chlorophyll $(\mathrm{Chl})$ extraction, ten leaf disks $(0.7 \mathrm{~cm}$ in diameter) were obtained from the third upper leaves of the main stems of five plants from each plot at the pegging, pod-setting, pod-filling, and mature stages, respectively. Leaf disks were soaked in $15 \mathrm{ml}$ of $95 \%$ ethanol for $48 \mathrm{~h}$. The Chl contents were calculated as described by Li et al. (2000).

Determination of wet gluten content processing quality: The bromophenol blue water solution, isopropanol lactic acid mixture, and the settling values were determined by shock. The landing value was measured using the Landing Numerical Measurer $(F N-I V)$. The Micro Dough LAB, a micro powder instrument was produced by a Botone $(S C B)$ (Sweden) and it measured the fluidity of bread. The wet gluten content and gluten index were measured using the Gluten Index Meter (MJZ-II, China) quality analyzer. For quality analysis, dough mixed from $200 \mathrm{~g}$ of flour was divided into $0.25 \mathrm{~g}$ samples and the wet gluten content was calculated using the following formula (Noor et al. $2020 \mathrm{a})$ : wet gluten $[\%]=\left[\left(100 \%\right.\right.$ flour $+2 \mathrm{ml} \mathrm{H}_{2} \mathrm{O}+10 \%$ salt $) / 100] \times 0.25 \mathrm{~g}$ flour.
The dry gluten was obtained by drying the wet gluten in an oven (TD5G, Hunan Xiang Li Scientific Instruments, Ltd., China) to constant mass at $100^{\circ} \mathrm{C}$ for $24 \mathrm{~h}$ using the air oven drying method. The dried gluten was left cool for $1 \mathrm{~h}$ before taking its mass as the dry gluten content. The percentage of dry gluten was calculated: dry gluten [\%] $=$ (mass of dry gluten $[\mathrm{g}] / 0.25 \mathrm{~g}$ flour) $\times 100$.

Determination of the spike number: Comparison of the spike of interest with the model spike occurs in an $\mathrm{N}$-dimensional vector space, which dimensions are defined by the total spikelet number of the spike of interest. The geometrical difference in grain yield distributions along the spike (GYDAS) between the two spikes is based on the scalar product of these two vectors:

$\cos a[\vec{a} \times \vec{b}]=\frac{\vec{a} \times \vec{b}}{|\vec{a}| \times|\vec{b}|}$

Statistical analysis: The different data were subjected to analysis of variance (ANOVA) as split-plot design using DPS and SAS 9.0. Graphics were constructed using Microsoft Excel 2010. Mean values were calculated and significance of the difference between treatments was tested by LSD (least significant difference) method at the significance level of $P=0.05$.

\section{Results}

Photosynthetic characteristics: The concentration of $\mathrm{CO}_{2}$ between the flag leaf cells after WSS and DS decreased gradually with the grouting process and from 7 to $28 \mathrm{~d}$ after anthesis, $P_{\mathrm{N}}$ increased with the amount of nitrogen applied showing a single peak increase trend. The $P_{\mathrm{N}}$ after 7-14 d of flowering was still the highest at N180 and not significantly different from N270 and N240. After flowering during $21-28 \mathrm{~d}, P_{\mathrm{N}}$ increased with nitrogen application and after $21 \mathrm{~d}$ of flowering was higher at N240 with significant difference from other treatments (Fig. $2 A$ ). After flowering at $28 \mathrm{~d}$, N240 was still the highest but the difference was not significant compared to N180, N210, and N270. The addition of nitrogen fertilizer can significantly improve the $P_{\mathrm{N}}$ of the flag leaves after flowering but the treatment effect of N270 in the later grouting was weaker and the WSS with N240 could sustain the whole grout period. $C_{\mathrm{i}}$ in the flag leaves decreased first and then increased with the increase of the nitrogen concentration at different stages after flowering. $C_{\mathrm{i}}$ under the N240 treatment was significantly lower than that of other treatments at 7-14 d and $21 \mathrm{~d}$ after flowering. $C_{\mathrm{i}}$ was the lowest in N240 treatment at $28 \mathrm{~d}$ after flowering, but the difference was not significant compared to N270 (Fig. 2B). Addition of nitrogen fertilizer after flowering could significantly reduce intercellular $\mathrm{CO}_{2}$ concentration of the flag leaves and the whole grouting period of wheat could completely continue. The $g_{\mathrm{s}}$ of the flag leaves of wheat significantly decreased gradually with the process of growing in WSS and DS and the $g_{\mathrm{s}}$ of the flag leaves increased first and then decreased with an increase of nitrogen concentration at different stages after flowering. The $g_{\mathrm{s}}$ was significantly higher in 


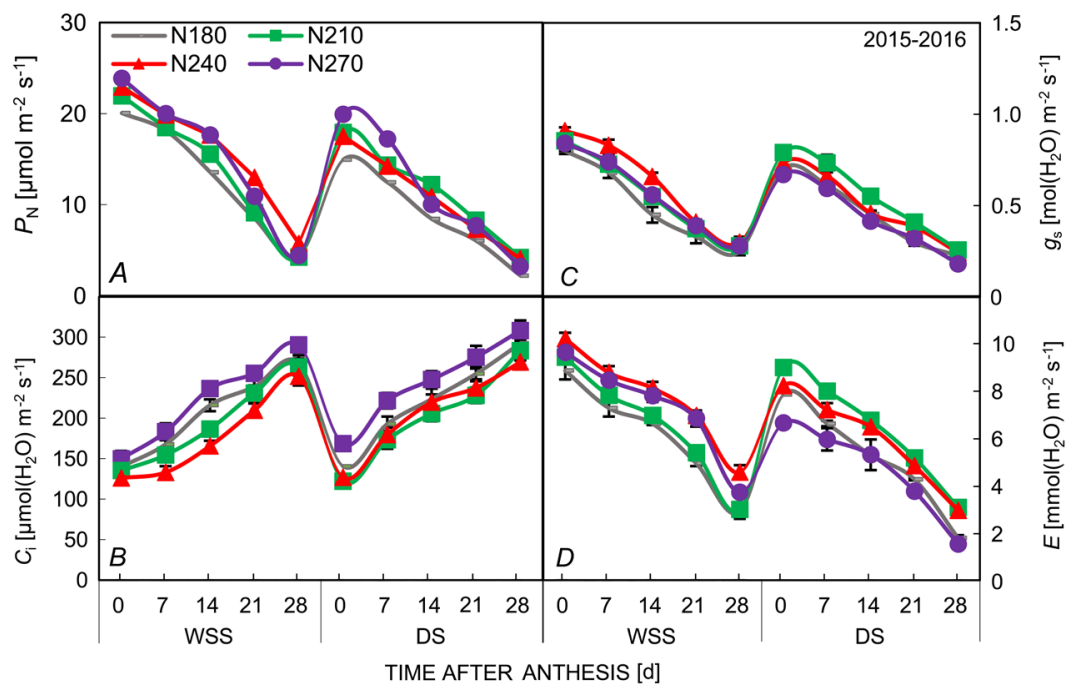

Fig. 2. Effect of sowing method on net photosynthesis $\left(P_{\mathrm{N}}\right)(A)$, substomatal $\mathrm{CO}_{2}$ concentration $\left(C_{\mathrm{i}}\right)(B)$, stomatal conductance $\left(g_{\mathrm{s}}\right)(C)$, and transpiration rate $(E)(D)$ in flag leaves of winter wheat after anthesis at different growth stages. WSS - wide-space sowing; DS - drill sowing.
N240 treatment compared to other treatments. The $g_{\mathrm{s}}$ was significantly the lowest in N240 at $14 \mathrm{~d}$ after flowering and the highest at 21-28 d in N240 but the difference there was not significant (Fig. 2C). The increased concentration of nitrogen fertilizer could significantly increase $g_{\text {s }}$ of flower flag leaves, but the effect lasted until the middle stage of growth and then weakened in the later stage. The $E$ of flag leaves decreased gradually with the grouting process and increased first and then decreased with the increase of nitrogen concentration at different stages after flowering. It can be seen from Fig. $2 D$ that the $E$ was significantly higher in N240 and N270 treatments than that of other treatments at $0-7,14$, and $21 \mathrm{~d}$ after flowering. After $28 \mathrm{~d}$ of flowering, $E$ was significantly higher in N240 than that in other treatments. Increasing $\mathrm{N}$ fertilizer can significantly enhance $E$ of flag leaves after flowering and the highest $E$ was observed in N240 and WSS.

Correlation analysis: The correlation between photosynthetic characteristics of flag leaves and yield after anthesis was analyzed. Yield was positively correlated with the net photosynthetic rate of flag leaves at 21 and $28 \mathrm{~d}$ after anthesis. It was significantly positively correlated with the $C_{\mathrm{i}}$ of flag leaves $14 \mathrm{~d}$ after anthesis, and extremely significantly positively correlated with the $C_{\mathrm{i}}$ of flag leaves at 21 and $28 \mathrm{~d}$ after anthesis. The stomatal conductance of flag leaves was significantly positively correlated from 0 to $21 \mathrm{~d}$ after flowering. The transpiration rate of flag leaves in all post-anthesis periods was significantly positively correlated (Fig 3; Table 1S, supplement). It can be seen that WSS enhanced the net photosynthesis of flag leaves in the late stage of grain filling, reduced the intercellular carbon dioxide concentration of flag leaves in the late stage of grain filling, enhanced the stomatal conductance of flag leaves in the early stage of grain filling, and increased the transpiration rate of flag leaves in the early stage of grain filling, thus realizing the yield increase.

Effects of different sowing methods and $N$ fertilizer rates on grain protein yield:: The effect of nitrogen fertilizers on grain protein and components was significantly different (Table 1). The contents of albumin and globulin (soluble protein) increased first and then decreased with the increase of nitrogen application. The highest value of albumin was in N240 and the difference between N240 and N270 was not significant. The contents of glutenin (storage protein) increased with the increase of nitrogen application and the highest content was observed in N240 and N270. The protein contents were significantly higher in N240 than that of other nitrogen applications treatments. Thus, it was obvious that N240 treatment regulated the storage protein and was more conducive to quality improvement.

Wheat yield and compositional factors were more common than regular strips with a significant increase in spike, yield, and an increased number of spikes (Table 2). The number of spikes, grain number per spike,

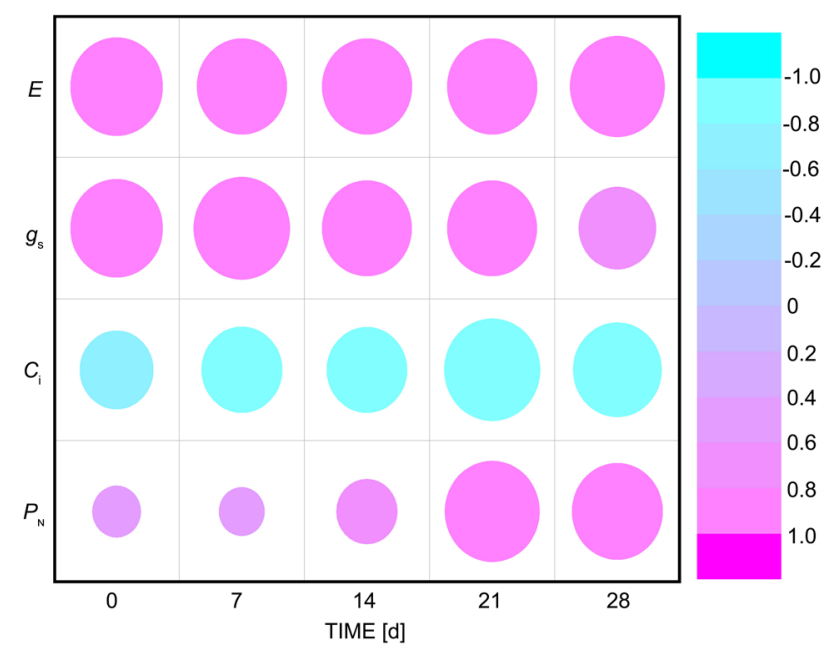

Fig. 3. Correlation coefficients between photosynthetic characteristics and yield in winter wheat. Net photosynthetic rate $\left(P_{\mathrm{N}}\right)$, intercellular $\mathrm{CO}_{2}$ concentration $\left(C_{\mathrm{i}}\right)$, stomatal conductance $\left(g_{\mathrm{s}}\right)$, transpiration rate $(E)$. Circle size and color bar indicate the correlation coefficients between photosynthetic characteristics and yield. Pink and blue color indicate the highest and lowest value of correlation coefficients, respectively. 
the 1,000-grain mass, and yield showed the trend of first increasing and then decreasing with the increase of nitrogen fertilizers application. The yield and its three elements were the highest in N240 and spike number and yield were significantly different from other nitrogen treatments and under DS. The yield and its constituent elements were the highest in N210 and the spike and yield was significantly different from other nitrogen treatments. With the increased nitrogen rate, the three factors of yield increased first and then decreased. For WSS and DS, the yield and three elements were the highest at N240 and N210, respectively.

Effect of sowing method on the photosynthesis characteristics of the flag leaves: Growth process of winter wheat after flowering on $P_{\mathrm{N}}$ of flag leaves showed a trend of a continuous decrease, with a large decrease in the early to middle grouting (Fig. $4 A$ ). The photosynthetic rates were the highest at different stages of WSS treatment. It can be seen that different sowing methods can promote the photosynthesis of flag leaves after flowering. Widespace sowing especially promoted the early and middle stage of grouting. With the growth process of winter wheat after flowering, the $E$ of flag leaves showed a trend of continuous decrease and the decrease was significant from the middle to the end of grouting (Fig. $4 B$ ). The $E$ was the highest at different stages of WSS treatment. It can be seen that different sowing methods can promote transpiration of flag leaf after flowering, especially at the end of grouting. During the growth process of winter wheat after flowering, $C_{\mathrm{i}}$ showed a trend of a continuous increase, with a large increase in the early to middle grouting (Fig. $4 \mathrm{C}$ ). The intercellular $\mathrm{CO}_{2}$ was the highest at different post-flowering stages of WSS treatment. It can be seen that different sowing methods can promote the increase of intercellular $\mathrm{CO}_{2}$ in the middle and late stage of grout, among which the WSS can also promote the flowering stage and the early stage of grout. With the growth process of winter wheat after flowering, the $g_{\mathrm{s}}$ of flag leaves showed a trend of a continuous decrease, with a significant decrease from the initial stage to the middle stage of grouting (Fig. 4D). Compared to DS, the $g_{\mathrm{s}}$ in WSS at different stages after flowering increased by $40 \%$. It can be seen that different sowing methods can improve the $g_{\mathrm{s}}$ of flag leaves after flowering, especially promote the late grouting. Among them, except for the early stage of grouting, the performance of WSS was the best.

Effects of sowing method on protein, protein components in grain and yield components at maturity stage: The mature grain protein, albumin, gliadin, gluten, and protein yield were improved by WSS, as compared to DS (Table 3). The protein content and protein yield significantly increased by 13 and $42 \%$ under WSS as compared to DS, respectively. The grain protein, globulin, gliadin, and glutenin were the highest by DS method, while albumin and grain protein yield were the highest by WSS method.

The yield at WSS was higher than that of the DS (Table 4). The increase in number of spikes was $22 \%$ and the increase in grain yield was $25 \%$ in WSS as compared to DS. The difference between sowing methods was not significant on 1000-grain mass. The number of spikes and grain yield were the highest under WSS and the grain

Table 1. Effect of different nitrogen rate on grain protein and component contents of winter wheat at maturity stage. N180, N210, N240, and N270 denote nitrogen application concentrations of 180, 210, 240, and $270 \mathrm{~kg}(\mathrm{~N}) \mathrm{ha}^{-1}$, respectively. Values are means $\pm \mathrm{SD}(n=5)$. Different letters denote significant differences at $p<0.05$.

\begin{tabular}{lllllllc}
\hline Nitrogen treatment & Albumin [\%] & Globulin [\%] & Gliadin [\%] & Glutenin [\%] & Glu/Gli & Protein [\%] & Protein yield [kg ha-1] \\
\hline N180 & $2.12^{\mathrm{b}}$ & $1.80^{\mathrm{Ab}}$ & $3.04^{\mathrm{c}}$ & $4.26^{\mathrm{d}}$ & $1.40^{\mathrm{a}}$ & $11.92^{\mathrm{c}}$ & $962.22^{\mathrm{c}}$ \\
$\mathrm{N} 210$ & $2.20^{\mathrm{b}}$ & $1.80^{\mathrm{Ab}}$ & $3.94^{\mathrm{b}}$ & $5.24^{\mathrm{c}}$ & $1.33^{\mathrm{b}}$ & $13.40^{\mathrm{b}}$ & $1,050.77^{\mathrm{b}}$ \\
$\mathrm{N} 240$ & $2.58^{\mathrm{a}}$ & $1.93^{\mathrm{a}}$ & $4.03^{\mathrm{b}}$ & $5.92^{\mathrm{b}}$ & $1.47^{\mathrm{a}}$ & $14.79^{\mathrm{a}}$ & $1,282.54^{\mathrm{a}}$ \\
$\mathrm{N} 270$ & $2.46^{\mathrm{a}}$ & $1.95^{\mathrm{a}}$ & $4.30^{\mathrm{a}}$ & $5.81^{\mathrm{b}}$ & $1.35^{\mathrm{b}}$ & $14.03^{\mathrm{b}}$ & $1,087.29^{\mathrm{b}}$ \\
\hline
\end{tabular}

Table 2. Effect of different sowing methods on yield component contents of winter wheat. DS - drill sowing; WSS - wide-space sowing. $\mathrm{N} 180, \mathrm{~N} 210, \mathrm{~N} 240$, and N270 denote nitrogen application concentrations of $180,210,240$, and $270 \mathrm{~kg}(\mathrm{~N}) \mathrm{ha}^{-1}$, respectively. Values are means $\pm \operatorname{SD}(n=5)$. Different letters denote significant differences at $p<0.05$.

\begin{tabular}{|c|c|c|c|c|c|}
\hline Sowing method & Nitrogen treatment & Spike number $\left[\times 10^{4} \mathrm{ha}^{-1}\right]$ & Grain number per spike & 1000 -grain mass $[\mathrm{g}]$ & Yield $\left[\mathrm{kg} \mathrm{ha}^{-1}\right]$ \\
\hline \multirow[t]{4}{*}{ WSS } & N180 & $716.50^{\mathrm{c}}$ & $29.73^{\mathrm{b}}$ & $40.66^{b}$ & $7,447.64^{\mathrm{c}}$ \\
\hline & $\mathrm{N} 210$ & $728.25^{\mathrm{c}}$ & $30.56^{\mathrm{a}}$ & $41.35^{\mathrm{Ab}}$ & $7,841.61^{\mathrm{b}}$ \\
\hline & $\mathrm{N} 240$ & $823.25^{\mathrm{a}}$ & $31.52^{\mathrm{a}}$ & $42.58^{\mathrm{a}}$ & $9,234.26^{\mathrm{a}}$ \\
\hline & $\mathrm{N} 270$ & $758.75^{\mathrm{b}}$ & $30.95^{\mathrm{a}}$ & $39.07^{\mathrm{b}}$ & $8,003.31^{\mathrm{b}}$ \\
\hline \multirow[t]{4}{*}{ DS } & N180 & $560.25^{\mathrm{e}}$ & $29.88^{\mathrm{b}}$ & $40.73^{b}$ & $5,857.49^{f}$ \\
\hline & $\mathrm{N} 210$ & $628.50^{\mathrm{d}}$ & $30.40^{\mathrm{a}}$ & $42.10^{\mathrm{a}}$ & $6,921.53^{\mathrm{d}}$ \\
\hline & $\mathrm{N} 240$ & $587.50^{\mathrm{d}}$ & $29.10^{\mathrm{b}}$ & $41.28^{\mathrm{ab}}$ & $6,092.60^{\mathrm{f}}$ \\
\hline & $\mathrm{N} 270$ & $540.00^{\mathrm{e}}$ & $28.02^{\mathrm{Bc}}$ & $39.92^{\mathrm{b}}$ & $5,087.64^{\mathrm{g}}$ \\
\hline
\end{tabular}




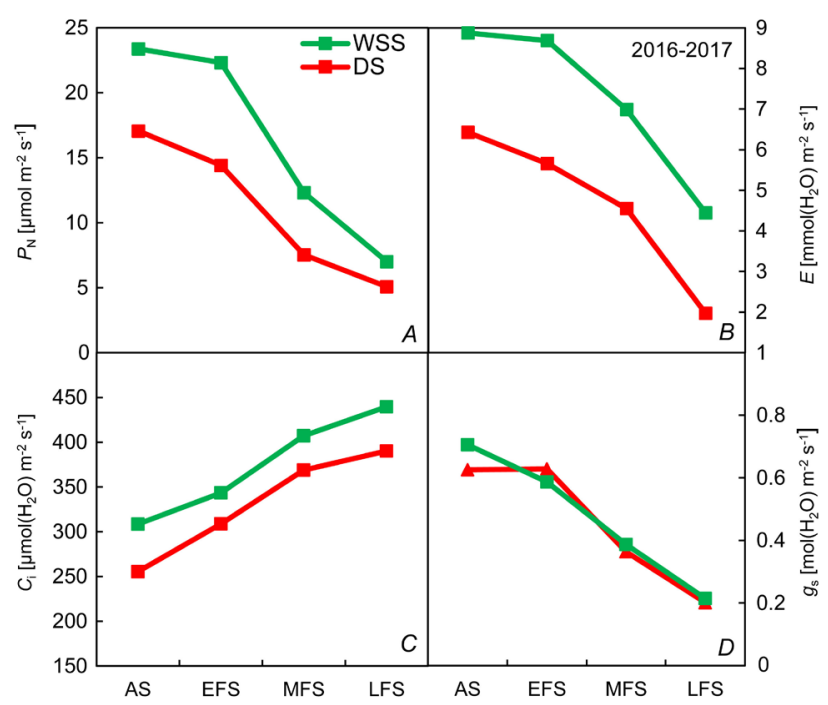

Fig. 4. Effects of sowing method on net photosynthesis $\left(P_{\mathrm{N}}\right)(A)$, transpiration rate $(E)(B)$, substomatal $\mathrm{CO}_{2}$ concentration $\left(C_{\mathrm{i}}\right)(C)$, and stomatal conductance $\left(g_{\mathrm{s}}\right)(D)$ in flag leaves of winter wheat after anthesis at different growth stages. AS, EFS, MFS, and LFS indicate anthesis stage, early grain-filling stage, middle grainfilling stage, and late grain-filling stage, respectively.

number per spike was significantly higher in WSS. It can be seen that different sowing methods mainly increase the yield by increasing the number of spikes.

\section{Discussion}

Effect of different nitrogen rate on sowing methods and photosynthesis characteristics of flag leaves after flowering: Increased photosynthesis improves the wheat yield (Parry et al. 2011), whereas $\mathrm{N}$ deficit can impair wheat development and yield-insufficient photosynthesis (Guerfel et al. 2009, Jia et al. 2015). In the present study, $\mathrm{N}$-deficit conditions reduced the $P_{\mathrm{N}}$ of the flag leaves and spikes in winter wheat during the grain-filling period, and this effect was significant for the drought-sensitive sowing. Compared to the continuing decrease of $P_{\mathrm{N}}$ in the flag leaves, $P_{\mathrm{N}}$ in spikes changed steadily after anthesis under drought conditions. Tambussi et al. (2005) have shown that $P_{\mathrm{N}}$ of wheat spikes seems to be maintained under water stress compared to the flag leaves, which was consistent with our results. The reduction in the $C_{\mathrm{i}}$, which we observed in the flag leaves, indicated earlier senescence during anthesis under $\mathrm{N}$ treatment, which may result from different sowing methods, but it can improve the $P_{\mathrm{N}}$ of flag leaves after flowering (Huseynova 2012). Conversely, the relative stability of nitrogen content in spike bracts might help sustain the duration of spike photosynthesis during the grain-filling period, particularly in drought-resistant sowing (Martinez et al. 2003). Stomatal conductance, an important biological process, reflects the carbon accumulation and transpiration in plants with $\mathrm{CO}_{2}$ flowing into sites of photosynthesis by the stomata (Sikder et al. 2015). It is possible that $g_{\mathrm{s}}$ might play an important role in the high $P_{\mathrm{N}}$ under both normal and nitrogen conditions (Farquhar and Sharkey 1982, Johnson et al. 1987). In the present study, $g_{\mathrm{s}}$ showed a lower reduction in both flag leaves and spikes under higher nitrogen compared to sowing during the middle and late grain-filling stages. In contrast, $g_{\text {s }}$ in flag leaves was more sensitive to drought than that of spikes. Saeidi and Abdoli (2015) showed that the decline in $P_{\mathrm{N}}$ may occur due to decreased $g_{\mathrm{s}}$ in wheat, and a similar result was observed in mulberry (Lakshmi et al. 1996, Rodgers et al. 2012). In addition, variations in leaf $E$ in wheat occured due to differences in $g_{\text {s }}$ (Morgan and LeCain 1991, Martin et al. 1994). In our study, sowing method reduced $E$ of both flag leaves and spikes in winter wheat. There was a significant decline in $E$ under drought conditions similarly as reported by van den Boogaard et al. (1997). It has been reported that the intercellular $\mathrm{CO}_{2}$ concentration, transpiration rate, and net photosynthetic rate of wheat generally increased and became stable with the appropriate nitrogen application. Thus, nitrogen application with a proper dose could be beneficial for wheat during the grain-filling period. The results of this study showed that the photosynthetic indexes in the flag leaves of the broad drill with $240 \mathrm{~kg}$ (fertilizer) $\mathrm{ha}^{-1}$ all reached the optimal level which may be due to the appropriate nitrogen fertilizer amount promoting the synthesis of chlorophyll (Song et al. 2016). Photosynthetic rate, stomatal conductance, transpiration rate, and chlorophyll content are important components of photosynthetic characteristics of crops. Nitrogen is the main element of protein synthesis and important component of grain closely related to the life activities of crops and an indispensable nutrient-limiting factor in agricultural production. As a result, nitrogen has been applied extensively in agricultural production over the past few decades to increase wheat yields. However, some studies have shown that under the conditions of high nitrogen application, the photosynthetic rate of leaves decreased. Moreover, applying excessive amounts of nitrogen fertilizer in agriculture leads to the soil pollution, release of harmful gases into the atmosphere, and the eutrophication of waters (Wang and Li 2010, Noor et al. 2020b). Wide-space sowing (WSS) and nitrogen application N240 increased the $g_{\mathrm{s}}$ of flag leaves during the grain filling and significantly decreased it at post-anthesis. WSS with N240 was the best for wheat production and yield. In addition, the correlation between photosynthetic characteristics and yield of winter wheat after flowering showed that the WSS enhanced the flag leaf $P_{\mathrm{N}}$ in the late grain-filling stage and the flag leaf $C_{\mathrm{i}}$ in the early grain-filling stage, which increased the yield. The transpiration rate increased by $126 \%$, the intercellular $\mathrm{CO}_{2}$ concentration increased by $21 \%$, and flag leaf stomatal conductance increased by $40 \%$ in WSS as compared to DS. The light transmittance of the large WSS and DS wheat population was significantly better than that of the traditional row spacing sowing wheat which could significantly adjust the net photosynthetic characteristics of the flower flag leaves. The drill sowing with $240 \mathrm{~kg} \mathrm{ha}^{-1}$ improved the photosynthetic characteristics of flag leaves, significantly increased the net photosynthetic rate, stomatal conductance, and transpiration rate of flag leaves 
Table 3. The protein components and protein yield of wheat under different sowing methods. Values are means $\pm \mathrm{SD}(n=5)$. Different letters denote significant differences at $p<0.05$.

\begin{tabular}{lll}
\hline & Wide-space sowing & Drill sowing \\
\hline Albumin [\%] & $2.27^{\mathrm{a}}$ & $1.93^{\mathrm{a}}$ \\
Globulin [\%] & $1.87^{\mathrm{Ab}}$ & $1.82^{\mathrm{Ab}}$ \\
Gliadin [\%] & $4.18^{\mathrm{a}}$ & $3.52^{\mathrm{b}}$ \\
Glutenin [\%] & $4.83^{\mathrm{a}}$ & $4.11^{\mathrm{b}}$ \\
Protein content [\%] & $14.18^{\mathrm{b}}$ & $12.54^{\mathrm{d}}$ \\
Protein yield [kg ha $\left.{ }^{-1}\right]$ & $1,298.0^{\mathrm{a}}$ & $917.2^{\mathrm{d}}$ \\
\hline
\end{tabular}

Table 4. Effects of different sowing methods on yield component contents of winter wheat. Values are means $\pm \mathrm{SD}(n=5)$. Different letters denote significant differences at $p<0.05$.

\begin{tabular}{lll}
\hline & Wide-space sowing & Drill sowing \\
\hline Spike number $\left[\times 10^{4} \mathrm{ha}^{-1}\right]$ & $850.9^{\mathrm{a}}$ & $695.0^{\mathrm{d}}$ \\
Grain number per spike & $31.26^{\mathrm{a}}$ & $31.01^{\mathrm{Ab}}$ \\
1000 -grain mass $[\mathrm{g}]$ & $40.35^{\mathrm{Ab}}$ & $39.19^{\mathrm{b}}$ \\
Yield $\left[\mathrm{kg} \mathrm{ha}^{-1}\right]$ & $9,049.1^{\mathrm{a}}$ & $7,266.5^{\mathrm{d}}$ \\
\hline
\end{tabular}

after flowering and significantly reduced the intercellular carbon dioxide concentration.

Effect of different sowing methods and nitrogen rate on nitrogen fertilizer: Increasing the amount of nitrogen fertilizer can increase the nitrogen content of wheat field tillage layer and promote nitrogen concentration in wheat plants. During maturity stage, the nitrogen in the range of 120 to $240 \mathrm{~kg} \mathrm{ha}^{-1}$ increased the accumulation of $\mathrm{N}$ in various organs but reduced the rate of nitrogen accumulation in wheat grain. According to Zhang et al. (2009), when nitrogen application increased before the operation, the accumulation of $\mathrm{N}$ in wheat organs at the maturity stage increased significantly but the nutrient in organs after flowering did not increase significantly. The results of this study also showed that the nitrogen accumulation before flowering increased and then decreased. The contribution rate of nitrogen to grain before flowering also increases and then decreases significantly with the increase of nitrogen accumulation. The reason for the analysis may be that water-soluble fertilizer needs to be increased synchronously with increasing the amount of nitrogen applied but the lack of water in wheat fields reduced the uptake of nitrogen fertilizer by the plant, which is not conducive to the accumulation of nitrogen in the plant (Chai and Xing 2010, Guo et al. 2018). At the same time, the response of wheat with a high gluten, medium gluten, and weak gluten content to $\mathrm{N}$ fertilizer was very different with increasing $\mathrm{N}$ application (Cao et al. 2005). To address this problem, many studies have focused on improving fertilization management by splitting up $\mathrm{N}$ applications, selecting a proper fertilization time, optimizing fertilizer application rate, and investigating new fertilizer types that ensure an adequate amount of $\mathrm{N}$ available as required by the crop to maximize yields (Wang 1997, Yang et al. 2013). Better management practices and the appropriate use of $\mathrm{N}$ fertilizers are convenient and effective ways to meet crop $\mathrm{N}$ demands, as long as the timing and rate of applications meet the agronomic optimum that would ensure the desirable yield (Tilman et al. 2002, Stevens et al. 2005). At the same rate, splitting $\mathrm{N}$ applications and proper timing of $\mathrm{N}$ supply are critical for meeting plant needs and improving $\mathrm{N}$ uptake (Limon-Ortega et al. 2000). Previous studies found that the quantity of N180 derived from basal $\mathrm{N}$ was lower in grain than that in straw, whereas the N210 and N240 was higher in grain than that in straw (Yang et al. 2011).

The total protein content and different protein components of wheat grains increased significantly with the increase of nitrogen application. The analysis of the ratio of protein components to total protein in wheat seeds by nitrogen application in this experiment showed that the content of protein components increased, with the highest increase in albumin at $240 \mathrm{~kg} \mathrm{ha}^{-1}$, and the highest increase in globulin at $270 \mathrm{~kg} \mathrm{ha}^{-1}$ (Wang et al. 2015). The contents of gliadin and glutenin (storage protein) were the highest at N240. The protein content, and the protein yield were significantly higher at nitrogen concentration of $240 \mathrm{~kg} \mathrm{ha}^{-1}$. It was also found that albumin and globulin were more regulated by nitrogen fertilizer in the early stage of grouting, while gliadin and glutenin were more sensitive to nitrogen fertilizer in the late stage of grouting. However, it was also reported that grain globulin and gliadin increased with the increase of nitrogen application, while albumin and gluten content tended to decrease.

Effects of sowing methods on growth and yield characteristics of wheat: The wide-space sowing improved the light conditions for the population in the field, and at the same time, the suitable nitrogen application made the use of resources reasonable. The nutrient conditions were high in individual plants which developed larger green leaf area, and senescence of the whole wheat plant was delayed (Hu et al. 2016). Study showed that leaf photosynthesis was closely related to crop yield and leaf photosynthetic rate was an important reason for crop high yield while nitrogen fertilizer could enhance plants' ability to synthesize chlorophyll and was one of the most effective factors to regulate plant leaf photosynthetic capacity (Fuentes et al. 2003, Li et al. 2015). The relative water content of wheat at the grain-filling stage was in the range of $50-80 \%$. With the increase of soil moisture, the protein content of grains showed a gradual decline (Zhang et al. 2006). We showed that the soil moisture content during the whole growth period was within the range of $50-80 \%$ of the maximum water-holding capacity in the field. As the soil moisture increased, the protein content of the grains gradually decreased. Under the conditions of this test, the water content in the growing period showed a significant positive correlation with the protein content of the grains. The wide-space sowing had a high water consumption in the growing period, high grain protein content, and high grain (Zhang et al. 2009). Research showed that 
the use of wide-stubble sowing enabled robust growth of wheat individuals and significantly increased wheat grains, improved water absorption, wet gluten content, sedimentation value, and significantly increased wheat drought tolerance (Wang et al. 2016). The grain ratio is related to different growth stages, nitrogen accumulation prior to flowering, and wet gluten content. It can be seen that increasing the wide-space sowing is the most beneficial to improve the grain quality indicators, such as protein and component contents, grain number per spike, wet gluten content, while the nitrogen fertilizer was beneficial to improving the nutritional quality and processing quality of wheat. Increasing nitrogen fertilizer was beneficial to improving the content of protein.

Conclusions: Photosynthetic rate, stomatal conductance, and transpiration rate of flag leaves at different stages after flowering increased and the intercellular $\mathrm{CO}_{2}$ concentration was reduced. Wide-space sowing with nitrogen of $240 \mathrm{~kg} \mathrm{ha}^{-1}$ improved photosynthetic characteristics of flag leaves and promoted the high yield. The photosynthetic rate was the highest in different stages of WSS after flowering; the number of spikes, 1,000-grain mass, and grain yield also increased in WSS as compared to DS. Therefore, wide-space sowing with nitrogen concentration of $240 \mathrm{~kg} \mathrm{ha}^{-1}$ could be an efficient strategy to improve wheat yield in Loess Plateau area.

\section{References}

Abbad H., El Jaafari S., Bort J., Araus J.L.: Comparison of flag leaf and ear photosynthesis with biomass and grain yield of durum wheat under various water conditions and genotypes. Agronomie 24: 19-28, 2004.

Bort J., Febrero A., Amaro T., Araus J.L.: Role of awns in ear water-use efficiency and grain weight in barley. - Agronomie 14: 133-139, 1994

Bubier J.L., Smith R., Juutinen S. et al.: Effects of nutrient addition on leaf chemistry, morphology, and photosynthetic capacity of three bog shrubs. - Oecologia 167: 355-368, 2011.

Cao C.F., Kong L.C., Wang J.L. et al.: [Effects of nitrogen application on yield, quality and nutrient absorption of wheat with strong and medium gluten.] - Plant Nutr. Fert. 1: 46-50, 2005. [In Chinese]

Carr D.J., Wardlaw I.F.: Supply of photosynthetic assimilates to grain from flag leaf and ear of wheat. - Aust. J. Biol. Sci. 18: 711-719, 1965.

Chai Y.J., Xing Y.S.: [Effects of nitrogen application on nitrogen accumulation and operation of different winter wheat varieties.] - Acta Bot. Sin. Northwestern 30: 2040-2046, 2010. [In Chinese]

Chen S.P., Bai Y.F., Zhang L.X., Han X.G.: Comparing physiological responses of two dominant grass species to nitrogen addition in Xilin River Basin of China. - Environ. Exp. Bot. 53: 65-75, 2005.

Evans L.T., Wardlaw I.F., Fischer R.A.: Wheat. - In: Evans L.T. (ed.): Crop Physiology: Some Case Histories. Pp. 101-150. Cambridge University Press, Cambridge 1975.

Farquhar G.D., Sharkey T.D.: Stomatal conductance and photosynthesis. - Ann. Rev. Plant Physio. 33: 317-345, 1982.

Fuentes P.J., Flurry M., Huggins D.R., Bezdicek D.F.: Soil water and nitrogen dynamics in dryland cropping systems of Washington State, USA. - Soil Till. Res. 71: 33-47, 2003.
Guerfel M., Beis A., Zotos T. et al.: Differences in abscisic acid concentration in roots and leaves of two young olive (Olea europaea L.) cultivars in response to water deficit. - Acta Physiol. Plant. 31: 825-831, 2009.

Guo L., Shi J.S., Wang L.Y.: [Effects of nitrogen application on nitrogen uptake and utilization and soil nitrate nitrogen content in summer maize under integrated drip irrigation with water and fertilizer.] - Chin. J. Ecol. Agr. 26: 668-676, 2018. [In Chinese]

Hikosaka K.: Interspecific difference in the photosynthesis nitrogen relationship: patterns, physiological causes, and ecological importance. - J. Plant Res. 117: 481-494, 2004.

Hu M.Y., Menf Y., Zhang Y.J.: [Research progress on the effects of water and nitrogen interaction on crop physiological characteristics and nitrogen utilization.] - J. Wheat Crops 36: 332-340, 2016. [In Chinese]

Huseynova I.M.: Photosynthetic characteristics and enzymatic antioxidant capacity of leaves from wheat cultivars exposed to drought. - BBA-Bioenergetics 1817: 1516-1523, 2012.

Jia S., Lv J., Jiang S. et al.: Response of wheat ear photosynthesis and photosynthate carbon distribution to water deficit. Photosynthetica 53: 95-109, 2015.

Johnson R.C., Mornhinweg D.W., Ferris D.M., Heitholt J.J.: Leaf photosynthesis and conductance of selected Triticum species at different water potentials. - Plant Physiol. 83: 1014-1017, 1987.

Lakshmi A., Ramanjulu S., Veeranjaneyulu K., Sudhakar C.: Effect of $\mathrm{NaCl}$ on photosynthesis parameters in two cultivars of mulberry. - Photosynthetica 32: 285-289, 1996.

Li G.T., Li B.G., Chen D.L.: Ammonia volatilization from large field planted with winter wheat and summer maize. - Acta Agric. Bor.-Sin. 17: 76-81, 2002.

Li J., Yao Y., Ding Z.: [Effects of furrow sowing on dry matter, soil water use efficiency and soil temperature of winter wheat populations.] - Crop Res. 24: 16-18, 2010. [In Chinese]

Li S.Y., Zhang. Y.S., Feng W. et al.: [Effect of Wide Belt Planting on water consumption characteristics of winter wheat.] Henan Agr. Sci. 44: 22-27, 2015. [In Chinese]

Li X.D., Wang X.Y., Zhang G.Y. et al.: [The regulation of nitrogen for peanut senescence.] - Sci. Agric. Sin. 33: 30-35, 2000. [In Chinese]

Liang Y.F., Khan S., Ren A.X. et al.: Subsoiling and sowing time influence soil water content, nitrogen translocation and yield of dryland winter wheat. - Agronomy 9: 37, 2019.

Limon-Ortega A., Sayre K.D., Francis C.A.: Wheat nitrogen use efficiency in a bed planting system in northwest Mexico. Agron. J. 92: 303-308, 2000

Liu C.G., Wang Y.J., Pan K.W. et al.: Effects of phosphorus application on photosynthetic carbon and nitrogen metabolism, water use efficiency and growth of dwarf bamboo (Fargesia rufa) subjected to water deficit. - Plant Physiol. Bioch. 96: $20-28,2015$

López-Bellido L., Muñoz-Romero V., Benítez-Vega J. et al.: Wheat response to nitrogen splitting applied to a Vertisols in different tillage systems and cropping rotations under typical Mediterranean climatic conditions. - Eur. J. Agron. 43: 24-32, 2012.

Ma W.Q., Zhang F.S., Zhang W.F.: [Fertilizer production and consumption and the resources, environment, food security and sustainable development in China.] - Resour. Sci. 27: 33-40, 2005. [In Chinese]

Mao Q.G., Lu X.K., Mo H. et al.: Effects of simulated N deposition on foliar nutrient status, $\mathrm{N}$ metabolism and photosynthetic capacity of three dominant understory plant species in a mature tropical forest. - Sci. Total Environ. 610611: $555-562,2018$. 
Martin B., Kebede H., Rilling C.: Photosynthetic differences among Lycopersicon species and Triticum aestivum cultivars.Crop Sci. 34: 113-118, 1994.

Martinez D.E., Luquez V.M., Bartoli C.G., Guiamét J.J.: Persistence of photosynthetic components and photochemical efficiency in ears of water-stressed wheat (Triticum aestivum).Physiol. Plantarum 119: 519-525, 2003.

Meng Q.F., Yue S.C., Hou P. et al.: Improving yield and nitrogen use efficiency simultaneously for maize and wheat in China: a review. - Pedosphere 26: 137-147, 2016.

Morgan J.A., LeCain D.R.: Leaf gas exchange and related leaf traits among 15 winter wheat genotypes. - Crop Sci. 31: 443448, 1991.

Noor H., Khan S., Sun M. et al.: Effect of different sowing methods and nitrogen rates on yield and quality of winter wheat in Loess Plateau of China. - Appl. Ecol. Env. Res. 18: 5701-5726, 2020a.

Noor H., Min S., Ren A.X. et al.: Effect of seeding rate on soil water consumption, yield and quality under wide space sowing of dryland winter wheat on the Loess Plateau in China. - Appl. Ecol. Env. Res. 18: 7167-7188, 2020 b.

O'Brien T.P., Sammut M.E., Lee J.W., Smart M.G.: The vascular system of the wheat spikelet. - Aust. J. Plant Physiol. 12: 487511,1985

Parry M.A.J., Reynolds M., Salvucci M.E. et al.: Raising yield potential of wheat. II. Increasing photosynthetic capacity and efficiency. - J. Exp. Bot. 62: 453-467, 2011.

Peñuelas J., Poulter B., Sardans J. et al.: Human-induced nitrogen phosphorus imbalances alter natural and managed ecosystems across the globe. - Nat. Commun. 4: 2934, 2013.

Rodgers V.L., Hoeppner S.S., Daley M.J., Dukes J.S.: Leaflevel gas exchange and foliar chemistry of common old-field species responding to warming and precipitation treatments. Int. J. Plant Sci. 173: 957-970, 2012.

Saeidi M., Abdoli M.: Effect of drought stress during grain filling on yield and components, gas exchange variables, and some physiological traits of wheat cultivars. - J. Agr. Sci. Tech. 17: 885-898, 2015.

Sikder S., Foulkes J., West H. et al.: Evaluation of photosynthetic potential of wheat genotypes under drought condition. Photosynthetica 53: 47-54, 2015.

Song M., Li Z., Feng H. et al.: [Characteristics of dry matter accumulation and yield effect of winter wheat at different water and nitrogen levels.] - Chin. J. Agr. Eng. 32: 119-126, 2016. [In Chinese]

Stevens W.B., Hoeft R.G., Mulvaney R.L.: Fate of nitrogen-15 in a long-term nitrogen rate study: I. Interactions with soil nitrogen. - Agron. J. 97: 1037-1045, 2005.

Sun M., Deng Y., Gao Z.Q. et al.: Effects of tillage in fallow period and sowing methods on water storage and grain protein accumulation of dryland wheat. - Pak. J. Agr. Sci. 52: 1-8, 2015.

Tambussi E.A., Bort J., Guiamet J.J. et al.: The photosynthetic role of ears in $\mathrm{C}_{3}$ cereals: Metabolism, water use efficiency and contribution to grain yield. - Crit. Rev. Plant Sci. 26:
1-16, 2007.

Tambussi E.A., Nogués S., Araus J.L.: Ear of durum wheat under water stress: water relations and photosynthetic metabolism. Planta 221: 446-458, 2005.

Tao Z., Wang D., Ma S. et al.: Light interception and radiation use efficiency response to tridimensional uniform sowing in winter wheat. - J. Integr. Agr. 17: 566-578, 2018.

Teare I.D., Law A.G., Simmons G.F.: Stomatal frequency and distribution on the inflorescence of Triticum aestivum. - Can. J. Plant Sci. 52: 89-94, 1972.

Tilman D., Cassman K.G., Matson P.A. et al.: Agricultural sustainability and intensive production practices. - Nature 418: $671-677,2002$.

Triboi E., Triboi-Blondel A.M.: Productivity and grain or seed composition: a new approach to an old problem. - Eur. J. Agron. 16: 163-186, 2002.

van den Boogaard R., Alewijnse D., Veneklaas E.J., Lambers H.: Growth and water-use efficiency of 10 Triticum aestivum cultivars at different water availability in relation to allocation of biomass. - Plant Cell Environ. 20: 200-210, 1997.

Wang C.B.: [Optimum rates of nitrogen fertilizer in cropping system of wheat (winter) and groundnut in Shandong province, China.] - Int. Acad. Newsl. 17: 70-71, 1997. [In Chinese]

Wang H., Yu Z., Zhang Y. et al.: Effects of tillage regimes on water consumption and dry matter accumulation in dryland wheat. - Acta Agron. Sin. 38: 675-682, 2012.

Wang M., Zhao G.C., Shi S.B.: [Effects of nitrogen application on post flowering photosynthetic characteristics and nitrogen distribution and grain protein components of wheat with different grain colors at maturity stage.] - Chin. J. Wheat Crops 35: 829-835, 2015. [In Chinese]

Wang S., Qi H., Wang Y. et al.: [Effects of seeding rate and seeding mode on wheat growth and development and yield under wheat-cotton intercropping mode.] - J. Shandong Agr. Univ. 48: 39-43, 2016. [In Chinese]

Wang X.C., Li J.: Evaluation of crop yield and soil water estimates using the EPIC model for the Loess Plateau of China. - Math. Comput. Model. 51: 1390-1397, 2010.

Yang J.S., Li S.X., Wu J.X. et al.: [Effect of controlled-release fertilizer on peanut yield and dry matter accumulation.] Shandong Agr. Sci. 45: 98-100, 2013. [In Chinese]

Yang Y., Wang X., Dai K. et al.: Fate of labeled urea- ${ }^{-15} \mathrm{~N}$ as basal and topdressing applications in an irrigated wheat-maize rotation system in North China plain: II summer maize. Nutr. Cycl. Agroecosys. 90: 379, 2011.

Zhang S., Lövdahl L., Grip H. et al.: Effects of mulching and catch cropping on soil temperature, soil moisture and wheat yield on the Loess Plateau of China. - Soil Till. Res. 102: 78-86, 2009 .

Zhang Y., Yang W., Bai J. et al.: [Characteristics of synergistic changes in winter wheat yield and grain protein content and water and fertilizer regulation.] - China Agr. Sci. 39: 24492458, 2006. [In Chinese]

(C) The authors. This is an open access article distributed under the terms of the Creative Commons BY-NC-ND Licence. 